\title{
The Effect of Current Ratio and Debt to Equity Ratio on Stock Prices with Return on Equity as an Intervening Variable in Food and Beverage Companies
}

\author{
Christia, Eka Nurmala Sari, Enda Noviyanti SimoranJkir, Galumbang Hutagalung \\ Universitas Prima Indonesia, Indonesia \\ Email: endanovitantisimoranpkir@unprimdn.ac.id, ctia04758@gmail.com, \\ galumbanghutagalung@unprimdn.ac.id, ekanurmala@umsu.ac.id
}

\section{ARTICLE INFO}

Date received : 27 December 2020

Revision date : 19 February 2021

Date received : 03 March 2021

\section{Keywords:}

Current Ratio

Debt to Equity Ratio

Stock Price

Return on Equity

\section{ABSTRACT}

This study aims to test and analyze the effect of Current Ratio and Debt to Equity Ratio on stock prices with ROE as an intervening variable. This research is a quantitative research. The population of food and beverage companies is 23 companies using purposive sampling technique, so samples that meet the criteria for analysis are 13 companies. The data were analyzed using multiple linear regression analysis, the ccrefficient of determination, the $\mathrm{F}$ test, and the $T$ test. The results showed that the Current Ratio had a positive and significant effect on ROE and stock prices. DER has a positive and significant effect on ROE but has a significant negative effect on stock prices and ROE has a positive and significant effect on stock prices. CR and DER have an indirect effect on stock prices through ROE. 


\section{INTRODUCTION}

A company is said to be successful if it is able to carry out its management functions properly, including financial management. In general, the goal of financial management is to maximize firm value, one of which can be achieved by increasing the company's net income. information about the profit or rate of return obtained by the company which is reflected in the financial statements will cause a reaction to the company's stock price. If the profit earned by the company is high, then $t$ he dividends that will be distributed to shareholders are also high so that many investors are interested in investing in the company. Conversely, if the profits earned by the company are low, then the dividends that will be distributed to shareholders will be low so that it will reduce the interest of investors to invest in the company.

Current assets consist of cash, accounts receivable and inventories. In practice, companies often accumulate inventory that is too high, which can cause damage and cause losses to the company. The liquidity ratio can be used to measure how liquid a company is. Current Ratio comparison between current assets and current debt. This ratio shows how far the guidance of short-term creditors is fulfilled by assets that are estimated to be cash in the same period as the maturity of the debt. The current ratio available in a company must be sufficient, not too small because it can hinder daily operational needs, but the current rat io level cannot be too large because it can reduce efficiency which results in a low rate of return on equity.

Companies that usually ch<xise to use debt will have a high level of risk for the interest charged by creditors. Companies need to analyze the leverage ratio so that the company can maintain a safe limit for the use of debt. DER shows the measure of $t$ he level of use of total debt to the capital owned by the company

The higher the DER, the greater the total debt composition compared to the total equity itself, from the above average DER decreases each year, this shows the smaller the company's burden on outsiders (creditors). The low debt burden borne by the company can increase the amount of profit the company receives.

The importance of the liquidity aspect can be seen by considering the impact that comes from the company's inability to meet its short -term obligations. Lack of liquidity can prevent the company from gaining profits or opportunities to earn profits. Another important thing is related to the aspect of profitability, which is a tool for making company profit projections because it illustrates the correlation between profits and the amount of capital invested.
ROE is the main goal of all companies, without Return on Equity, the business will not last in the long run. Return on Equity can measure how much the company makes a gain in terms of sales, assets and profits for its own capital. Management is required to increase revenue or operating profit, to finance all company activities, add assets and pay off company liabilities. The measure of the success of a manager can be seen from the ability to create Return on Equity. Increasing Return on Equity is the most important task for a manager. Managers are constantly looking for ways to change the company in order to increase Return on Equity.

Companies can maximize their profit if the financial manager knows the factors that have a big influence on the company's Return on Equity. By knowing the effect of each factor on ROE, the company can determine steps to overcome problems and minimize the negative impacts that arise. All the factors that occur in a company have an influence on the company's ability to earn a profit. To maximize each of these factors, it is necessary to have asset management, cost management, and debt management.

Food \& beverage companies are the most stable companies because despite the global economic crisis, food and beverage companies are still able to survive and remain undisturbed. In addition, in a good economic condition or a bad economy, it will not have a major impact on decreasing people's purchasing power because the goods produced in food and beverage companies are basic human needs. However, there are still several forxl and beverage companies that suffer losses due to the tight competition between local and imported products so that these companies cont inue to improve product quality and increase production capacity to grab consumers which will increase company profits. This condition motivates investors to own shares. Investors need the financial information of a company to evaluate the company through a fundamental approach that focuses on financial ratios.

There are 23 food and beverage companies listed in Indonesia Stock Exchange, but not all companies can achieve profit so there are 6 companies that cannot achieve consecutive profits from 2015 - 2018.

The stock price is a very important factor and must be considered by investors in investing because the stuck price shows the performance of the issuer. The movement of stock prices is in line with the performance of the issuer, if the issuer has a better performance, the greater the profits it will get from business operations. The stock price also shows the value of a company and is the right index for the effectiveness of the company. The higher 
the share price, the higher the value of the company and vice versa. A stock price that is too low often means that the company is performing poorly. However, if the share price is too high it will reduce the ability of investors to buy the shares.

Research by (Pratama \& Erawati, 2014) shows the results of Current Ratio, Debt to Equity Ratio and Earning Per Share have a positive and significant effect on stock prices while Return on Equity has no effect on stock prices. different from the research results of (Kundiman \& Hakim, 2017) which show that the Current ratio and Debt to Equity Ratio have no effect on stock prices, ROA has a positive and significant effect on stock prices and ROE has a negative and significant effect on stock prices.

Due to differences in the results of previous studies, this study seeks to review the factors that affect stock prices. In addition, through this research, it will be known which shares have a certain price and the maximum profit per share for shareholders. 1s it from the food and beverage subsector that is more profitable, which are currently developing rapidly.

Based on the background and data description of this phenomenon, the researcher is interested in conducting a research entitled, "The Effect of Current Ratio and Debt to Equity Ratio on Stock Prices with Return on Equity as an Intervening Variable in Food and Beverage Companies Listed on the Indonesia Stock Exchange 2015-2018 Period. "

The objectives of this study are:

1. Testing and analyzing the effect of the current ratio on stock price in food and beverage companies for the period 20 IS- 2018.

2. Testing and analyzing the effect of the DER on stock price in food and beverage companies for the period 2015-2018.

3. Testing and analyzing the effect of the current ratio on return on equity in food and beverage companies for the period 2015-2018.

4. Test and analyze the effect of the DER on ROE in food and beverage companies for the period 2015-2018.

5. Testing and analyzing the effect of ROE on stock price in food and beverage companies for the pericd 2015-2018.

6. Test and analyze the effect of the current ratio on stock prices through return on equity as an intervening variable in food and beverage companies for the period 2015-2018.

7. Test and analyze the effect of DER on stock price through return on equity as an intervening variable in foc>d and beverage companies for the period 2015-2018
Literatur Review

Current Ratio

Current Ratio is how much current assets are available to cover short-term liabilities or debts that are due soon (Houston, 2010). Current Ratio is a comparison between total current assets and current debt. Lower CR can adversely affect a company's ability to pay its current obligations. When the company is unable to pay its current obligations, this will have a negative effect on increasing profits (Yudha Pratomo, 2019).

The current ratio shows the company's ability to pay its short-term liabilities using its current assets. The current ratio is one of the most common and frequently used liquidity ratios. The higher the current ratio, the greater the company's ability to pay its various bills. The higher this ratio, the more capable the company is to pay off its short- term obligations so that it will attract investors to buy shares in the company and will increase the share price (Houston, 2010).

Current ratio is a ratio that compares current asset accounts and current liabilities in order to determine a company's ability to pay off its shortterm obligations (Pratama \& Erawati, 2014).

The formula for calculating the current ratio $*$ 14]:

\section{Currentratio $\overline{\text { Current Ltabiltties }}$}

Debt to Equity Ratio

Debt to Equity Ratio (DER) is useful for knowing the amount of funds provided by creditors and company owner* (Houston, 2010). Debt to Equity Ratio (DER) is the ratio of debt to equit $y$. The higher the DER, the greater the total debt composition compared to the total equity itself, from the above average DER decreases each year, this shows the

smaller the company's burden on outsiders (creditors). The low debt burden borne by the company can increase the amount of profit the company receives (Joko Adityo Pratomo, 2017).

Debt to equity ratio, namely the ratio between total liabilities (total debt) and total equity (equity). This ratio shows the extent to which the capital itself guarantees all debt. The higher the debt to squity ratio, the greater the risk of creditors (including banks) because a high Debt to Equity Ratio means the lower the level of security of funds placed by creditors in the business. The lower debt to equity ratio means that the foreign capital used in the company's operations is getting smaller, so that the risk borne by investors will also be smaller and will be able to increase the stock price (Kasmir, 2016). 
Debt to Equity Ratio is a ratio that compares $t$ he amount of debt to equity. This

ratio is ofien used by investors to see how much debt the company owes compared to the equity owned by $t$ he company or its shareholders. The higher the Debt to Equity Ratio, it is assumed that the company has a higher risk of the company's liquidity. The smaller the Debt to Equity Ratio, the better for the company and will increase the stock price(Kasmir, 2016).

The formula for calculating the debt to equity ratio *(T. Darmadji and Fakhruddin, 2015):

\section{Stock Price}

$$
\mathrm{DER}=\frac{\text { lotal Debt }}{\text { Equity }}
$$

Shares are a sign of a statement or ownership of a person or entity in a company or limited liability company. Shares are in the form of a sheet of paper which states that the owner of the paper is the owner of the company that issues the securities (Kasmir, 2016).

Stock Price is a price that is ready to be accepted by other parties to have ownership rights in the company, the share price in value can change every time it is so fast, the rise and fall of the company's share price depends on the demand and supply. between the buyer and the seller of the stock (Hartini \& Rosadi, 2019).

Share prices are based on expected cash flows in the coming years, not just the current year. So, maximizing the share price asks us to look at operations in the long run (Suryawan \& Wirajaya, 2017).

Stock price can change up or down in a very fast time. Stock prices can change in a matter of minutes or even seconds. This is based on the supply and demand between the buyer of shares and the seller of shares (Kundiman \& Hakim, 2017).

A share price is the price of a share in an ongoing market. According to Law No. 8 of 1995 concerning the Capital Market, in essence, the share price is the acceptance of the amount of sacrifice that must be made by every investor for participation in the company. If the stock exchange market is closed, the market price is the closing price (Hartini \& Rosadi, 2019).

\section{Return on Equity}

Return on Equity (ROE) is a ratio used to show the efficient use of own capital. The higher this ratio, the better because the position of the company owner is getting stronger $I$. Return on Equity (ROE) is a comparison between net profit after tax and total equity. The increase in ROE indicates a success for the company in obtaining profits, on the contrary, if the ROE value is low, it indicates a problem in financial management at the company (Joko Adityo Pratomo, 2017). The profitability ratio is a ratio to assess a company's ability to seek profit. This ratio also provides a measure of the company's management effectiveness. The general purpose of profitability ratios is to (Suryawan \& Wirajaya, 2017):

1. Measure or calculate the profit generated,

2. Assess the progress of profit over time,

3. Assessing the amount of net profit after tax with own capital,

4. Measure the productivity of the company from all company funds used both loan capital and own capital. And S. Other objectives.

Meanwhile, the benefits obtained are:

1. Knowing $t$ he level of profit .

2. Knowing $\mathrm{t}$ he progress of profit from time to time.

3. Knowing the amount of net profit after tax with own capital.

4. Knowing the productivity of all company funds used, both loan capital and own capital.

Return on Equity (ROE) is for the owner of capital this ratio is more important than the ratio of net income to sales, which is to find out how far the results are obtained from their investment. Therefore, what is compared is net income with equity or equit $y$. Equity is defined as all equity, equity is sometimes referred to as net assets. For companies, this analysis is important because it is an attractive factor for investors to invest (Kasmir, 2016).

States the return on equity formula is as follo (Suryawan \& Wirajaya, 2017):

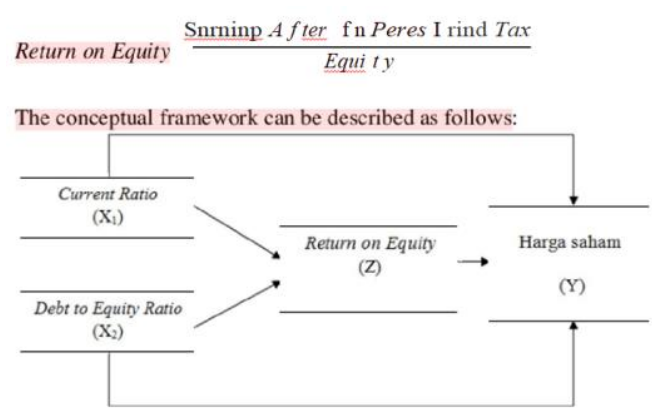

Based on the formulation of the initial problem and the conceptual framework that has been described, the hypotheses developed in this study are as follows:

H1: Current Ratio affects stock prices in fr>nd and beverage companies listed on the Indonesia Stock Exchange for the period $2015-2018$.

H2: Debt to Equity Ratio affects stock prices in food and beverage companies listed on the Indonesia Stock Exchange for the perir>d 2015-2018 
H3: Current Ratio affects Return on Equity in fr>nd and beverage companies listed on the Indonesia Stock Exchange for the peri<xt 2015-2018

H4: Debt to Equity Ratio has an effect on Return on Equity in food and beverage companies listed on the 1ndonesia Stock Exchange for the period 20152018.

H5: Return on Equit y affects stock prices on food and beverage companies listed on the Indonesia Stock Exchange for the period 2015-2018

H6: Current Rat io affects stock prices through Return on Equity as an intervening variable in food and beverage companies listed on the Indonesia Stock Exchange for the period 2015-2018.

H7: Debt to Equity Ratio affects stock prices through Return on Equity as an intervening variable in food and beverage companies listed on the Indonesia Stock Exchange for the period 20152018

\section{METODE}

This research is a quantitative research. the quantitative approach is research data in the form of numbers and analysis using statistics (Houston, 2010).

The population used in this study is the annual financial statements of companies incorporated in the $f\langle x\rangle d$ and beverage sector on the Indonesia Stock Exchange for the period 2015-2018. The population in this study were 23 companies.

The sample used in this study were 13 companies with a total of 52 observation data on companies that are members of the fo<xl and beverage sector listed on the Indonesia Stock Exchange for the 2015-2018 period.

The first step in this research is to determine the population, namely food and beverage companies listed on the Indonesia Stock Exchange which are published in the 2018 Fact Book. Based on the recorded population, not all populations can be sampled because there are companies that do not publish financial re\}xirts and experience losses during the study period. Furthermore, the researcher will calculate the ratio data based on the indicators of each variable and perform data analysis using the classical assumption test, multiple linear regression and hypothesis testing.

\section{RESULTS AND DISCUSSION}

A. Pan Aiiafysis.

Substructural Equation Test Results 1

Substructure equation I : $\mathrm{Y}=\mathrm{a}+\mathrm{bl} \mathrm{X} 1+$ $b 2 X 2+b 3 Z+e$

Substructure equation $I$ is used to test the effect of the variables Current Ratio, Debt to Equity Ratio and Return on Equity on stuck prices. The substructure equation test 1 was carried out using multiple linear regression analysis through the coefficient of determination and the $\mathrm{t}$ statistical test. The results of the substructure equation test 1 can be seen in table 4.4 below:.

Table 4.7 Results of the Determination Coefficient Test of the Effect of Current Ratio, Debt to Equity Ratio and ROE on Stock Prices Model summary^

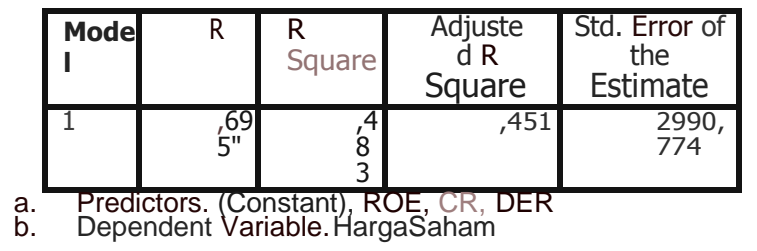

Based on Table 4.9 above the value of $\mathrm{R}$ Square is 0.185 which means that the ability of the Current Ratio and Debt to Equity Ratio variables can explain the variation of the Return on Equity variable by $18.5^{\circ} \mathrm{e}$ and the remaining $81.5^{\circ} / \mathrm{c}$ is explained by other variables in beyond the model.

Based on table 4.9 above, it can also be obtained that the value of e2 - ' ( I- R') - ' (1-0.185) $=0.903$.

Table 1

T-test results. Effect of CR and DER on ROE Cneflicients

\begin{tabular}{lcrrrr}
\hline Model & \multicolumn{2}{c}{$\begin{array}{l}\text { Unstandardzed } \\
\text { Coeflcients }\end{array}$} & \multicolumn{2}{c}{$\begin{array}{c}\text { Standardized } \\
\text { Coefficients }\end{array}$} & \multirow{2}{*}{ Sig. } \\
\cline { 2 - 5 } & $\mathrm{B}$ & \multicolumn{1}{c}{ Std. Error } & \multicolumn{1}{c}{ Beta } & & \\
\hline (Constant) &,- 221 &, 147 & & $\mathbf{- 1 , 5 0 4}$ &, 139 \\
CR &, 058 &, $02 \mathrm{~b}$ &, 407 & $\mathrm{y}, 184$ &, 034 \\
DER &, 329 &, 099 &, 619 & 3,318 &, 002 \\
\hline
\end{tabular}

a. Dependent Variable. ROE

The table value for the probability of 0.05 at degrees of freedom $n-k-I=52-2-1=49$ is 2.00958. Thus the results of the $t$ test can be explained as follows:

1. The value of $t$ count $>t$ table or 2.184> 2.00958 and significant $0.034<0.05$, then $\mathrm{Ha}$ is accepted, meaning that partially the Current Ratio has a positive and significant effect on Return on Equity in food and beverage companies listed on the Indonesia Stock Exchange in 2015 -2018. 
2. The value of $t$ count $>t$ table or 3.318> 2.00958 and significant $0.002<0.05$, then $\mathrm{Ha}$ is accepted, meaning that partially the Debt to Equity Ratio has a positive and significant effect on Return on Equity in food and beverage companies listed on the Indonesia Stock Exchange 2015-2018.

\section{The Effect of Current Ratio on Stock Price}

The results of testing the first hypothesis can be seen that the Current Rat io effect on stock price in food and beverage companies listed on the Indonesia St $<x k$ Exchange for the pericd 2015-2018. This is indicated by the $t$ value of 2.216 which is greater than the t-table value of 2.01063 , and the significance value of 0.030 is smaller than the alpha value of 0.05 .

The higher this ratio, the more capable the company is to pay off its short-term obligations so that it will attract investors to buy shares in the company and will increase the share price (Haryono, 2016). The results of this study are in line with (Pratama \& Erawati, 2014), namely the Current Ratio has a significant effect on stock prices. Current Ratio can be used as a basis for determining the ups and downs of stock prices. This is because companies that have a high Current Ratio are considered to be more able to pay off their short-term obligations so that they will attract investors to buy shares in the company and will increase the share price.

\section{The Effect of Debt to Equity Ratio on Stock Price}

The results of testing the second hypothesis can be seen that the Debt to Equity Ratio has a negative and significant effect on stock price in food and beverage companies listed on $t$ he Indonesia Stock Exchange for the 2015 -2018 period. This is indicated by the value of $t$ count of 2,503 is smaller than the value of -t table 2.01063 , and the si gnificance value of 0.016 is smaller than the alpha value of 0.05 .

If a company has a large enough amount of debt, then their performance is said to be poor and less capable of attracting investors to invest in the company. So that it can be concluded, a company that has a high amount of debt or a high DER level has the potential to reduce stock prices ( $T$. Darmadji and Fakhruddin, 2015).

The results of this study are in line with (Pratama \& Erawati, 2014), namely the

Debt to Equit y Ratio has an effect on stock prices (LINANDA \& AFRIYENIS, 2018). DER can be used as a basis for determining the ups and downs of stock prices. The lower debt to equity ratio means that the foreign capital used in the company's operations is getting smaller, so that the risk borne by investors will also be smaller and will be able to increase the share price.

\section{The Effect of Current Ratio on ROE}

The results of testing the third hypothesis can be seen that the Current Ratio has a positive and significant effect on Return on Equity in food and beverage companies listed on the Indonesia Stock Exchange for the period 2015-2018.

This is indicated by the $t$ value of 2.184 which is greater than the $t$-table value of 2.00958 , and the significance value of 0.034 is smaller than the alpha value of 0.05 . CR has an effect on ROE, meaning that a company that has a high CR will also produce a high ROE. A high CR value indicates that the availability of current assets to pay off current liabilities is also high. who are large in companies, it is interpreted that the company has more sources of assets that can be converted into cash from company profits I - The results of this study are in line with (Hantono, 2015), namely the Current Ratio has an effect on ROE 12 2]. A high CR value indicates that the availability of current assets to pay off current liabilities is also high. It can also be seen that the average Current Ratio is above $200 \% / e$ which indicates that it is considered a go<xl enough measure for the company because it is good enough to pay off short-term debt with the assets it owns.

\section{The Effect of DER on ROE}

The results of testing the fourth hypothesis can be seen that the Debt to Equity Ratio has a positive and significant effect on Return on Equity in food and beverage companies listed on $t$ he Indonesia Stock Exchange for the $2015-2018$ period. This is indicated by the $t$ value of 3.318 which is greater than the table value of 2.00958 , and the significance value of 0.002 is smaller than the alpha value of 0.05 .

According to (Wardhana, Sultana, Mandang, \& Jim, 2011), the higher the DER, the greater the trust of outsiders, if the debt is large, indicating that the first priority is the source of funds from debt, this is contrary to the pecking order theory. However, according to the profitability theory, large debt will cause large debt costs, this is very possible for small company profits. Thus, the effect between DER and ROE is negat ive, this is supported by the pecking order theory which establishes a sequence of funding decisions in which managers will first choose to use retained earnings, then debt, and external equity as the last option.

The results of this study are in line with (Hantono, 2015), namely the Debt to Equity Ratio has an effect on ROE 1 (Yudha Pratomo, 2019) (Joko Adityo Pratomo, 2017). The use of debt can 
provide benefits that are greater than the costs that must be incurred by the company from the use of debt, thus in this case the use of debt provides benefits to the company because it provides stronger capital in support ing the activities of pr<xlucing $g<x>d s$ for sale.

\section{The Effect of Return on Equit y on Stock Price}

The results of testing the fifth hypothesis can be seen $t$ hat Return on Equity has a positive and significant effect on stock price in food and beverage companies listed on the Indonesia Stock Exchange for the period 2015-2018. This is indicated by the $t$ value of 6.642 which is greater than the t-table value of 2.01063, and the significance value of 0.000 is smaller than the alpha value of 0.05 .

Return on Equity (ROE) is for the owner of capital this ratio is more important than the ratio of net income to sales, which is to find out how far the results are obtained from their investment. Therefore, what is compared is net income with equity or equit y. Equity is defined as all equity, equity is sometimes referred to as net assets. For companies, this analysis is important because it is an attractive factor for investors to in yes (Kasmir, 2016).

The results of this study are in line with previous research by (Kundiman \& Hakim, 2017) which proved that the Return on Equity variable has a positive and significant effect on stock prices. ROE is used to measure the amount of ret urn on investment of shareholders. This figure shows how well management is making use of the investment of shareholders. ROE is measured in percent. The ROE level has a positive relationship with stock prices, so the greater the ROE the greater the market price, because the large ROE indicates that the returns that investors will receive will be high so $t$ hat investors will be interested in buying these shares, and this causes the stock market price to tend to ride.

\section{The Effect of Current Ratio on Stock Price through ROE}

The results of testing the sixth hypothesis can be seen that the Current Rat in has no effect on stock price through Return on Equity in food and beverage companies listed on the Indonesia Stock Exchange for the period 2015-2018. This is indicated by the $t$ value of 0.270 which is smaller than the $t$ table of 2.01063 .

A company that has liquid assets so large that it is able to fulfill all its financial obligations that must be fulfilled immediatel $y$, it is said that the company is liquid, and vice versa if a company does not have sufficient liquid assets to fulfill all its financial obligations that must be fulfilled immediately, it is said the company is insolvable. In the liquidity ratio, the ability of a company to use its current assets to pay off its current liabilities is stated in the current ratio. The higher this ratio, the higher the company's ability to pay off its shortterm debt, which in turn will increase investor confidence and increase share prices.

A high CR value is not necessarily good in terms of profitability. (El-Sawi \& Momen, 2005) states that a low CR will result in a decrease in the market price of the company's stock, but too high $\mathrm{CR}$ is not necessarily good because in certain conditions it shows that many company funds are unemployed (little activity) which in turn can reduce their ability. corporate profits.

The results of the study are in line with previous research by (Dwikirana \& Prasetiono, 2016) which states that the current ratio affects stock prices through profitability where companies that have a high CR means that they have a high level of liquidity. Companies that have a high $\mathrm{CR}$, the less liquidity risk borne by the company and investors, so that investors perceive this as a positive signal, as a result the value of profitability increases in the eyes of investors. The increase in the value of profitability will have an impact on increasing share prices.

\section{The Effect of DER on Stock Price through Return on Equity}

The results of testing the sixth hypothesis can be seen that the Debt to Equity Ratio has no effect on stock price through Return on Equity in food and beverage companies listed on the Indonesia Stock Exchange for the period 2015-2018. This is indicated by the $t$ value of 1.401 which is smaller than the $t$ table of 2.01063 .

Debt to equity ratio that is quite high indicates that the company's performance is getting worse, because $t$ he level of dependence of the company's capital on outside parties is getting bigger. Thus, if the company's debt to equity ratio is high, there is a possibility t hat the company's stock price will be low because if the company makes a profit, the company tends to use that profit to pay its debts rather than dividing dividends (Felany \& Worokinasih, 2018).

The results of this study are in line with previous research by (Yuliani, Kurniawan, \& Ghasarma, 2016) which stated that the debt to equity ratio affects stock prices through profitability, where financial leverage shows the ratio between total debt and total equit $y$, which is better known as DER. Companies in general can increase profitability which in turn increases their share price thereby increasing shareholder welfare and building greater growth potential. Companies that have DER continue to strive to maintain investor confidence by 
managing these funds so that they are able to pay off debts. The ability to pay off debt, the company tries to invest funds originating from debt as effectively as possible so that an optimal return is obtained for future capital.

Companies that have DER try to manage the loan funds for the company's operational activities as best as possible to increase the company's profitability which will increase investors' interest in investing.

\section{CONCLUSION}

The conclusions from the results of this study are:

Current Ratio has a positive significant effect on stock price in food and beverage companies listed on the Indonesia Stock Exchange for the period 2015 - 2018.

Debt to Equity Ratio has a negative significant effect on stock price in food and beverage companies listed on the Indonesia Stock Exchange for the period 20152018.

Current Ratio has a positive significant effect on ROE in food and beverage companies listed on the Indonesia Stock Exchange for the period 2015 2018.

DER has a positive significant effect on ROE in food and beverage companies listed on the Indonesia Stock Exchange for the perixxt 2015 2018.

Return on Equity has a positive significant effect on stock price in food and beverage companies listed on the Indonesia Stock Exchange for the 2015 - 2018 period

Current Ratio affects stock price through Return on Equity in food and beverage companies listed on the Indonesia Stock Exchange for the period 2015 - 2018.

DER affects stock price through Return on Equity in food and beverage companies listed on the 1ndonesia Stock Exchange for $t$ he period 2015 $-2018$

Suggestions from the results of this study are:

For this sector, it is advisable to pay attention to earnings because a higher ROE indicates a positive effect on its share price.

For investors, it is advisable to pay attention to the rate of return on ROE before deciding to invest in the company because it is proven that the higher the ROE level has a positive effect on stock prices which can increase the prosperity of shareholders.

For further researchers, it is recommended to use other variables such as Total Asset Turnover, Price Earning Ratio, Dividend Payout Ratio and others.

\section{REFERENCES}

Dwikirana, Sekar Aditya, \& Prasetiono, Prasetiono. (2016). Analisis pengaruh rasio profitabilitas, likuiditas, dan leverage terhadap return saham dengan nilai perusahaan sebagai variabel intervening. Diponegoro Journal of Management, 5(3), 612-626.

El-Sawi, S. A., \& Momen, F. M. (2005). Biology of some phytoseiid predators (Acari: Phytoseiidae) on eggs of Phthorimaea operculella and Spodoptera littoralis (Lepidoptera: Gelechiidae and Noctuidae). Acarologia, 45(1), 23-30.

Felany, Indah Ayu, \& Worokinasih, Saparila. (2018). Pengaruh Perputaran Modal Kerja, Leverage Dan Likuiditas Terhadap Profitabilitas (Studi Pada Perusahaan Sub Sektor Makanan Dan Minuman Yang Terdaftar Di Bursa Efek Indonesia Padatahun 2012-2016). Jurnal Administrasi Bisnis, 58(2), 119-128.

Hantono, Hantono. (2015). Pengaruh Current Ratio dan Debt To Equity Ratio Terhadap Profitabilitas pada Perusahaan Manufaktur Sektor Logam dan Sejenisnya yang Terdaftar di Bursa Efek Indonesia Periode 2009-2013. Jurnal Wira Ekonomi Mikroskil: JWEM, 5(1), 21-30.

Hartini, Estuti Fitri, \& Rosadi, Kartika Hernapuri. (2019). Pengaruh Kinerja Keuangan Terhadap Harga Saham Perusahaan Food and Beverages Yang Terdaftar Di Bursa Efek Indonesia. Jurnal Manajemen Kewirausahaan, 15(2), https://doi.org/10.33370/jmk.v15i2.222

Haryono, Azis Fathoni Indra Yugusna and Andi Tri. (2016). Pengaruh Gaya Kepemimpinan Demokratis Dan Lingkungan Kerja Terhadap Kinerja Dan Kedisplinan Karyawan (Studi Empiris Pada Perusahaan SPBU 44.501.29 Randu Garut Semarang). Journal Of Management, 23.

Houston, Eugene F. Brigham and Joel F. (2010). Dasar-Dasar Manajemen Keuangan. Jakarta: Salemba Empat.

Kasmir, Anoli. (2016). Myoron Kruonpon. Jakarta: Raja Grafindo Persada.

Kundiman, Adriana, \& Hakim, Lukmanul. (2017). Pengaruh Current Ratio, Debt To Equity Ratio, Return On Asset, Return On Equity Terhadap Harga Saham Pada Indeks Lq 45 Di Bei Periode 2010-2014. Among Makarti, 9(2).

LINANDA, RICO, \& AFRIYENIS, WINDA. (2018). Pengaruh Struktur modal dan profitabilitas terhadap Harga saham. JEBI (Jurnal Ekonomi 
Dan Bisnis Islam), 3(1), 135-144.

Pratama, Aditya, \& Erawati, Teguh. (2014). PENGARUH CURRENT RATIO, DEBT TO EQUITY RATIO, RETURN ON EQUITY, NET PROFIT MARGIN DAN EARNING PER SHARE TERHADAP HARGA SAHAM (Study Kasus Pada Perusahaan Manufaktur Yang Terdaftar Di Bursa Efek Indonesia Periode 2008-2011). Jurnal Akuntansi; Vol 2 No 1 (2014): JURNAL AKUNTANSI VOL. 2 NO. 1 JUNI 2014. Retrieved from https://jurnalfe.ustjogja.ac.id/index.php/akunta nsi/article/view/20

Pratomo, Joko Adityo. (2017). Pengaruh Debt to Equity Ratio (DER) Dan Current Ratio (CR) Terhadap Return on Equity (ROE). Studi Empiris Pada Perusahaan Sub Sektor Kabel Yang Terdaftar di Bursa Efek Indonesia Pada Tahun 2013-2016. Jurnal Administrasi Bisnis, 5(4), 942-956.

Pratomo, Yudha. (2019). APJII: Jumlah Pengguna Internet di Indonesia Tembus 171 Juta Jiwa. Kompas. Com.

Suryawan, I. Dewa Gede, \& Wirajaya, I. Gde Ary.
(2017). Pengaruh Current Ratio, Debt To Equity Ratio dan Return On Assets pada Harga Saham. E-Jurnal Akuntansi; Vol 21 No 2

(2017).

https://doi.org/10.24843/EJA.2017.v21.i02.p17

T. Darmadji and Fakhruddin. (2015). Poser Mural di Indonesia. Jakarta: Salemba Empat.

Wardhana, Datau E. A., Sultana, A., Mandang, V. V, \& Jim, E. (2011). The efficacy of Bacillus Calmette-Guerin vaccinations for the prevention of acute upper respiratory tract infection in the elderly. Acta Med Indones, 43(3), 185-190.

Yuliani, Yuliani, Kurniawan, Teddy, \& Ghasarma, Reza. (2016). Pengaruh likuiditas, financial leverage, aktivitas terhadap return saham dengan profitabilitas sebagai variabel mediasi. Jurnal Manajemen Dan Bisnis Sriwijaya, 14(1), 121-132. 